\title{
Case Report \\ Use of Chlorothiazide in the Management of Central Diabetes Insipidus in Early Infancy
}

\author{
Manish Raisingani, Resmy Palliyil Gopi, and Bina Shah \\ Department of Pediatrics, Division of Pediatric Endocrinology, New York University School of Medicine, New York, NY, USA \\ Correspondence should be addressed to Bina Shah; bina.shah@nyumc.org
}

Received 26 February 2017; Accepted 18 April 2017; Published 3 May 2017

Academic Editor: Atul Malhotra

Copyright (C) 2017 Manish Raisingani et al. This is an open access article distributed under the Creative Commons Attribution License, which permits unrestricted use, distribution, and reproduction in any medium, provided the original work is properly cited.

\begin{abstract}
Management of central diabetes insipidus in infancy is challenging. The various forms of desmopressin, oral, subcutaneous, and intranasal, have variability in the duration of action. Infants consume most of their calories as liquids which with desmopressin puts them at risk for hyponatremia and seizures. There are few cases reporting chlorothiazide as a temporizing measure for central diabetes insipidus in infancy. A male infant presented on day of life 30 with holoprosencephaly, cleft lip and palate, and poor weight gain to endocrine clinic. Biochemical tests and urine output were consistent with central diabetes insipidus. The patient required approximately 2.5 times the normal fluid intake to keep up with the urine output. Patient was started on low renal solute load formula and oral chlorothiazide. There were normalization of serum sodium, decrease in fluid intake close to 1.3 times the normal, and improved urine output. There were no episodes of hyponatremia/hypernatremia inpatient. The patient had 2 episodes of hypernatremia in the first year of life resolving with few hours of hydration. Oral chlorothiazide is a potential bridging agent for treatment of central DI along with low renal solute load formula in early infancy. It can help achieve adequate control of DI without wide serum sodium fluctuations.
\end{abstract}

\section{Introduction}

Central diabetes insipidus (DI) refers to the inability to conserve free water and is most commonly caused by hypothala$\mathrm{mic} /$ posterior pituitary lesions, resulting in impaired arginine vasopressin (AVP) production and release. In the neonatal period it may be associated with midline brain anatomic abnormalities such as septooptic dysplasia with agenesis of the corpus callosum, Kabuki syndrome, holoprosencephaly, and familial pituitary hypoplasia with absent stalk [1-4]. Infections involving the base of the brain, such as meningococcal, cryptococcal, listeria, and toxoplasmosis meningitis, congenital cytomegalovirus infection, and nonspecific inflammatory disease of the brain, can cause central diabetes insipidus in infancy [5-9]. Due to the deficiency of AVP, patients with central DI are unable to concentrate their urine and have a very low urine osmolality. They have to consume enormous amounts of water to keep up with the urine output. With fluid management alone these children can develop nonobstructive hydroureteronephrosis, bladder wall thickening and trabeculations, overflow incontinence, and impaired renal function requiring a drainage procedure [10]. Hence, vasopressin analogues have been used to help decrease urine output and increase urine concentrating ability.

One situation where vasopressin analogues may not always be readily used to manage central DI is infancy. The various forms of vasopressin analogues, oral, subcutaneous, or intranasal, have variability in duration of action with no established safety and efficacy data in early infancy [11-13]. Their use is associated with wide fluctuations in serum sodium $(\mathrm{Na})$ levels. In addition, infants have high obligate fluid requirement $(3 \mathrm{~L} / \mathrm{m} 2 /$ day $)$ and consume most of the calories as liquids. This high fluid intake along with desmopressin (DDAVP) puts them at an increased risk for hyponatremia and seizures. There have been a few case reports of managing central DI in early infancy using low renal solute load formula and chlorothiazide [14-16]. These patients were transitioned to DDAVP when the baby got older 
and started consuming more solid food. We report the case of a month-old baby with holoprosencephaly and central diabetes insipidus managed with oral chlorothiazide during infancy.

\section{Case Report}

A male infant presented on day of life (DOL) 30 to the endocrine clinic with holoprosencephaly, cleft lip, cleft palate, and poor weight gain. Baby was born at an outside hospital and transferred to our facility due to congenital defects of cleft lip and cleft palate. Baby was born, full term NSVD, with APGAR scores of 9 and 9 at 1 and 5 minutes. Pregnancy was complicated by gestational diabetes controlled with insulin. Immediate newborn course was complicated by polycythemia which resolved with partial exchange transfusion. Baby had normal Na levels $144 \mathrm{mmol} / \mathrm{L}$ on DOL 2 . Baby was transferred on DOL 15 for surgical evaluation and management to our facility. MRI of the brain revealed corpus callosum dysgenesis with partial absence of falx cerebri as well as mild colpocephaly and possible lobar holoprosencephaly. The baby's weight on DOL 15 was $8.5 \%$ below the birth weight. He had an uneventful course except for feeding issues due to cleft lip and cleft palate. Baby's feeding and weight gain improved on a high calorie formula and the baby was discharged on DOL 24 from the NICU. After the initial normal electrolytes, they were not repeated during the NICU hospitalization. Baby was referred to and seen in pediatric endocrine clinic on DOL 30 to evaluate pituitary function and was again noted to have poor weight gain and had gained only 115 grams over the birth weight. Serum $\mathrm{Na}$ level was $163 \mathrm{mmol} / \mathrm{L}$ and baby was admitted to the pediatrics unit.

Baby was noted to have a urine output of $8-11 \mathrm{cc} / \mathrm{kg} / \mathrm{hr}$ and required huge amounts of PO and IV fluids to keep up with the losses. Urine specific gravity $(<1.005)$ and urine osmolality $(\sim 100 \mathrm{mOsm} / \mathrm{kg})$ were consistent with central diabetes insipidus. Baby was started on IV vasopressin and IV fluids. On this management urine output and serum Na levels normalized. Baby had a gastrostomy tube placement on DOL 35 to provide adequate fluids/nutrition. Vasopressin drip was discontinued on DOL 37 and low renal solute load formula (RSL) was started the same day. Oral chlorothiazide was started on DOL 39. There was improvement in urine output $(4-5 \mathrm{cc} / \mathrm{kg} / \mathrm{hr})$ and serum $\mathrm{Na}$ levels normalized (Figure 1) with improved weight gain and the patient was discharged home on DOL 44. The treatment was initiated with a chlorothiazide dose of $2 \mathrm{mg} / \mathrm{kg} / \mathrm{day}$ and it was titrated based on serum Na levels to $6 \mathrm{mg} / \mathrm{kg} /$ day.

Results of the rest of the pituitary workup were normal: free T4 $1.30 \mathrm{ng} / \mathrm{dL}(16.73 \mathrm{pmol} / \mathrm{L})$, IGF-1 $38 \mathrm{ng} / \mathrm{mL}$ $(4.97 \mathrm{nmol} / \mathrm{L})$, and random cortisol $13.7 \mathrm{mcg} / \mathrm{dL}(378 \mathrm{nmol} / \mathrm{L})$. Genetic testing revealed a normal male karyotype with no abnormality seen on microarray. Repeat pituitary function testing has been normal with random cortisol $13.6 \mathrm{mcg} / \mathrm{dL}$ ( $375 \mathrm{nmol} / \mathrm{L})$, IGF-1 levels $55-69 \mathrm{ng} / \mathrm{mL}(7.19-9.02 \mathrm{nmol} / \mathrm{L})$, and free T4 levels 1.08-1.16 ng/dL (13.9-14.93 pmol/L).

The baby has been followed up in the outpatient clinic for 15 months with maintenance of $\mathrm{Na}$ levels near the higher

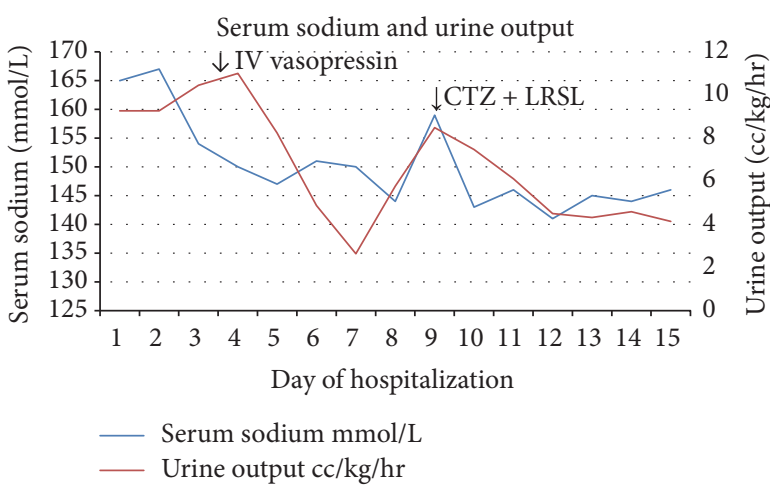

FIGURE 1: Serum sodium levels and urine output during hospitalization. CTZ: chlorothiazide; LRSL: low renal solute load formula.

end of normal. Baby had an admission at 7 months of age for respiratory distress and poor oral intake. The baby was not feeding well and mother was not using the gastrostomy tube. Mother also missed one dose of chlorothiazide. In the hospital, the baby was given home feeds via gastrostomy tube and IV fluids for a few hours, with which the baby did well and was discharged home. Since the baby is unable to take solid food due to cleft lip and palate, there has been slow weight gain. Pediasure which has a high renal solute load was added to the regimen at 11 months of age which led to an episode of hypernatremia (serum Na $162 \mathrm{mmol} / \mathrm{L}$ ). He was admitted and started on free water 15-20 cc with each feed and the episode resolved. The baby is being evaluated to undergo surgery by ENT for cleft lip and cleft palate after which he may be able to take solid food. The plan is to switch to oral DDAVP once the baby is able to consume most of the calories as solid food.

\section{Discussion}

The management of central DI in infancy is very challenging due to very few safe treatment options. There have been problems reported in literature with use of DDAVP in infancy as listed in Table 1. At one center, DDAVP was administered intranasally to four infants (0.5-2.5 $\mu$ g per dose) and subcutaneously to two infants ( $0.125 \mu \mathrm{g}$ per dose) who were diagnosed with central diabetes insipidus in infancy [12]. Three of six infants had at least one episode of hyponatremia (serum sodium $<130 \mathrm{mmol} / \mathrm{L}$ ). All infants had at least one episode of hypernatremia with serum $\mathrm{Na}>160 \mathrm{mmol} / \mathrm{L}$. Three infants required hospitalization for treatment of hyponatremia or hypernatremia $(174-189 \mathrm{mmol} / \mathrm{L})$. Other investigators have also reported variability in duration of action with using nasal and oral forms of DDAVP $[11,13,17]$. Rivas-Crespo et al. also reported an infant on intranasal DDAVP who had episodes of hypernatremia whenever he had a cold due to poor absorption and ultimately developed central myelinolysis during one of the episodes when serum $\mathrm{Na}$ was $189 \mathrm{mmol} / \mathrm{L}$ [18]. Blanco et al. had some success using subcutaneous form of DDAVP, although the dose needs to be carefully titrated. There were episodes of hyponatremia in five of the six patients treated with subcutaneous DDAVP, although it 
TABLE 1: Summary of cases of central diabetes insipidus in infancy.

\begin{tabular}{|c|c|c|c|c|c|c|c|}
\hline Author & $\begin{array}{c}\text { Age at } \\
\text { diagnosis in } \\
\text { days }\end{array}$ & Cause of DI & Treatment & $\begin{array}{l}\text { Age at } \\
\text { transition in } \\
\text { months to } \\
\text { DDAVP }\end{array}$ & Complications & $\begin{array}{l}\text { Number of } \\
\text { hypona- } \\
\text { tremia } \\
\text { episodes }\end{array}$ & $\begin{array}{l}\text { Number of } \\
\text { hyperna- } \\
\text { tremia } \\
\text { episodes } \\
\end{array}$ \\
\hline $\begin{array}{l}\text { Rivkees et al., } 5 \\
\text { infants }\end{array}$ & Early infancy & N/A & $\begin{array}{l}\text { BM or LRSL + } \\
\text { free water + } \\
\text { CTZ }\end{array}$ & $6-18$ & N/A & 0 & 1 episode \\
\hline Abraham et al. & $<7$ & $\begin{array}{l}\text { Septooptic } \\
\text { dysplasia }\end{array}$ & LRSL + HCTZ & 12 & FTT & 0 & 0 \\
\hline Abraham et al. & $<7$ & $\begin{array}{l}\text { Septooptic } \\
\text { dysplasia }\end{array}$ & LRSL + HCTZ & 3 & $\begin{array}{l}\text { Acute } \\
\text { gastroenteritis } \\
\text { with low K, } \\
\text { difficulty in } \\
\text { maintaining } \\
\text { sodium }\end{array}$ & 0 & 0 \\
\hline Abraham et al. & $<7$ & $\begin{array}{l}\text { Septooptic } \\
\text { dysplasia }\end{array}$ & LRSL + HCTZ & 6 & Failure to thrive & 0 & 0 \\
\hline Abraham et al. & $<7$ & Holoprosencephaly & LRSL + HCTZ & 12 & $\begin{array}{c}\text { FTT, } \\
\text { hypernatremia }\end{array}$ & 0 & 0 \\
\hline Chaudhary et al. & 10 & Holoprosencephaly & $\begin{array}{l}\text { Dilution of } \\
\text { formula }+ \\
\text { HCTZ }\end{array}$ & N/A & N/A & 0 & 0 \\
\hline $\begin{array}{l}\text { Pogacar et al., } 6 \\
\text { infants }\end{array}$ & Early infancy & $\begin{array}{l}\text { Holoprosencephaly } \\
\text { Trauma, panhy- } \\
\text { popituitarism, and } \\
\text { meningitis }\end{array}$ & $\begin{array}{c}\text { DDAVP: } \\
\text { intranasal, } \\
\text { subcutaneous }\end{array}$ & $\mathrm{N} / \mathrm{A}$ & $\begin{array}{c}3 \text { infants } \\
\text { hospitalized for } \\
\text { hypo- or } \\
\text { hypernatremia, } \\
1 \text { death due to } \\
\text { hyponatremic } \\
\text { seizure }\end{array}$ & At least 5 & At least 3 \\
\hline $\begin{array}{l}\text { Blanco et al., } 10 \\
\text { infants }\end{array}$ & Infancy & $\begin{array}{c}\text { Septooptic } \\
\text { dysplasia, } \\
\text { holoprosencephaly, } \\
\text { congenital nasal } \\
\text { piriform sinus } \\
\text { stenosis, group B } \\
\text { streptococcal } \\
\text { meningitis, and } \\
\text { congenital diabetes } \\
\text { insipidus }\end{array}$ & $\begin{array}{c}\text { DDAVP: } \\
\text { intranasal, } 4 \\
\text { patients } \\
\text { DDAVP: } \\
\text { subcutaneous, } 6 \\
\text { patients }\end{array}$ & $\mathrm{N} / \mathrm{A}$ & N/A & $\begin{array}{c}9 \text { out of } 10 \\
\text { patients had } \\
\text { hyponatremia }\end{array}$ & $\begin{array}{l}\text { Inpatient, } 9 \\
\text { episodes; } \\
\text { outpatient, } 5 \\
\text { episodes }\end{array}$ \\
\hline Yarber et al. & $<7$ days & NA & $\begin{array}{c}\text { DDAVP: } \\
\text { subcutaneous }\end{array}$ & N/A & N/A & N/A & N/A \\
\hline Rivas-Crespo et al. & 28 days & $\begin{array}{c}\text { Neonatal } \\
\text { hemorrhagic shock }\end{array}$ & $\begin{array}{c}\text { Subcutaneous }+ \\
\text { intranasal }\end{array}$ & N/A & $\begin{array}{l}\text { Central } \\
\text { myelinolysis at } \\
\text { age } 3 \text { due to } \\
\text { poor absorption } \\
\text { of intranasal } \\
\text { DDAVP }\end{array}$ & N/A & $\begin{array}{l}\text { Multiple } \\
\text { hyperna- } \\
\text { tremia on } \\
\text { intranasal } \\
\text { DDAVP }\end{array}$ \\
\hline
\end{tabular}

DDAVP: desmopressin, FTT: failure to thrive, BM: breast milk, LRSL: low renal solute load formula, CTZ: chlorothiazide, HCTZ: hydrochlorothiazide, and N/A: not available.

was asymptomatic and in most of the cases it took place initially when the dose was being adjusted. This dose needs to be carefully titrated, preferably in an inpatient setting [19]. There are some cases in literature reporting use of alternative treatments like carbamazepine [20], chlorpropamide [21, 22], and clofibrate [21, 23] for management of central diabetes insipidus. There is lack of data regarding their use in central diabetes insipidus in infancy and a concern for serious side effects like hypoglycemia [24] or increased mortality [20].

There have been a few case reports describing the use of chlorothiazide or hydrochlorothiazide along with low renal solute formula for the management of central diabetes insipidus in infancy as listed in Table 1. Rivkees et al. described successful treatment of central DI in 5 infants with 
chlorothiazide and using low RSL, breast milk, or diluting formula with water. The infants were transitioned to DDAVP between 6 and 18 months of age. Similarly, Abraham et al. described 4 cases with central DI diagnosed before 10 days of age. These infants were managed on hydrochlorothiazide and low RSL formula with transition to oral DDAVP between 3 and 12 months of age. Chaudhary et al. used hydrochlorothiazide with diluted formula to control serum sodium levels in an infant with holoprosencephaly and central DI.

Chlorothiazide is a drug used in the management of nephrogenic DI. The mechanism of action of chlorothiazide is not exactly known. The most widely accepted hypothesis suggests that the antidiuretic action of thiazides is secondary to increased renal sodium excretion. The renal sodium loss causes extracellular volume contraction leading to lowered GFR and increased proximal tubular sodium and water reabsorption. Hence, less water and solutes are delivered to the distal tubule and collecting duct and less are lost as urine $[25,26]$. It is unclear what the mechanism of action is in central DI but is believed to be due to the same process as described above. In addition using a low RSL formula (Sim PM 60/40 in our case) decreases the solute load on the kidney and hence causes a decrease in the obligate urine output.

Renal solute load (RSL) refers to all solutes of endogenous or dietary origin that require excretion by the kidneys. Potential renal solute load (PRSL) refers to solutes of dietary origin that would need to be excreted in the urine if none were diverted into synthesis of new tissue and none were lost through nonrenal routes. It is dependent on the nitrogen, sodium, chloride, potassium, and phosphorus content of the formula $[27,28]$. Low renal solute load formula helps decrease urine output as the amount of solutes that need to be excreted by the kidney is reduced. Sim PM 60/40 and breastmilk both have a $20-30 \%$ lower renal solute load than other commercially available formulas [16]. Hence substituting regular formula with low RSL formula or breast milk may help decrease urine output in patients with central DI.

In conclusion oral chlorothiazide may be a potential bridging agent for treatment of central DI along with low RSL formula, when diet is mostly fluids in early infancy. It can help achieve adequate control of DI without risks of wide serum sodium fluctuations. Transition to DDAVP should occur when these infants consume more solid food. More studies should be done evaluating chlorothiazide use for central diabetes insipidus in infancy.

\section{Additional Points}

This article discusses challenges faced in the management of central diabetes insipidus in infancy.

\section{Conflicts of Interest}

The authors have no conflicts of interest relevant to this article to disclose.

\section{References}

[1] N. Masera, D. B. Grant, R. Stanhope, and M. A. Preece, "Diabetes insipidus with impaired osmotic regulation in septooptic dysplasia and agenesis of the corpus callosum," Archives of Disease in Childhood, vol. 70, no. 1, pp. 51-53, 1994.

[2] R. Tawa, Y. Kaino, T. Ito, Y. Goto, K. Kida, and H. Matsuda, "A case of Kabuki make-up syndrome with central diabetes insipidus and growth hormone neurosecretory dysfunction," Acta paediatrica Japonica; Overseas edition, vol. 36, no. 4, pp. 412-415, 1994.

[3] S. Van Gool, F. de Zegher, L. S. de Vries et al., "Alobar holoprosencephaly, diabetes insipidus and coloboma without craniofacial abnormalities: a case report," European Journal of Pediatrics, vol. 149, no. 9, pp. 621-622, 1990.

[4] H. Yagi, K. Nagashima, H. Miyake et al., "Familial congenital hypopituitarism with central diabetes insipidus," The Journal of Clinical Endocrinology and Metabolism, vol. 78, no. 4, pp. 884889, 1994.

[5] M. Brandle, P. L. Vernazza, M. Oesterle, and R. L. Galeazzi, "Cerebral toxoplasmosis with central diabetes insipidus and panhypopituitarism in a patient with AIDS," Schweizerische Medizinische Wochenschrift, vol. 125, no. 14, pp. 684-687, 1995.

[6] C. Christensen and A. Bank, "Meningococcal meningitis and diabetes insipidus," Scandinavian Journal of Infectious Diseases, vol. 20, no. 3, pp. 341-343, 1988.

[7] W. Mena, S. Royal, R. F. Pass et al., "Diabetes insipidus associated with symptomatic congenital cytomegalovirus infection," The Journal of Pediatrics, vol. 122, no. 6, pp. 911-913, 1993.

[8] A. E. Sloane, "Transient diabetes insipidus following listeria meningitis," Irish Medical Journal, vol. 82, no. 3, pp. 132-134, 1989.

[9] A. Watanabe, R. Ishii, K. Hirano et al., "Central diabetes insipidus caused by nonspecific chronic inflammation of the hypothalamus: case report," Surgical Neurology, vol. 42, no. 1, pp. 70-73, 1994.

[10] D. Colliver, R. Storey, H. Dickens, and R. Subramaniam, "Nonobstructive urinary tract dilatation in children with diabetes insipidus," Journal of Pediatric Surgery, vol. 47, no. 4, pp. 752-755, 2012.

[11] B. Atasay, M. Berberoglu, A. Gunlemez et al., "Management of central diabetes insipidus with oral desmopressin in a premature neonate," Journal of Pediatric Endocrinology \& Metabolism: JPEM, vol. 17, no. 2, pp. 227-230, 2004.

[12] P. R. Pogacar, S. Mahnke, and S. A. Rivkees, "Management of central diabetes insipidus in infancy with low renal solute load formula and chlorothiazide," Current Opinion in Pediatrics, vol. 12, no. 4, pp. 405-411, 2000.

[13] B. Yarber and B. Wood, "Early diagnosis and treatment of diabetes insipidus in a newborn infant: a case study," Neonatal Network: NN, vol. 11, no. 8, pp. 17-20, 1992.

[14] M. B. Abraham, S. Rao, G. Price, and C. S. Choong, "Efficacy of Hydrochlorothiazide and low renal solute feed in Neonatal Central Diabetes Insipidus with transition to Oral Desmopressin in early infancy," International Journal of Pediatric Endocrinology, vol. 2014, no. 1, article 11, 2014.

[15] H. Chaudhary, B. K. Bhakhri, and V. Datta, "Central diabetes insipidus in newborns: unique challenges in management," Pediatric Endocrinology Reviews, vol. 9, no. 1, pp. 476-478, 2011.

[16] S. A. Rivkees, N. Dunbar, and T. A. Wilson, "The management of central diabetes insipidus in infancy: desmopressin, low renal 
solute load formula, thiazide diuretics," Journal of Pediatric Endocrinology \& Metabolism: JPEM, vol. 20, no. 4, pp. 459-469, 2007.

[17] A. Fjellestad-Paulsen, H. Crosnier, and P. Czernichow, "Central diabetes insipidus in the very young child. Treatment with oral desmopressin," Archives Francaises de Pediatrie, vol. 45, no. 10, pp. 787-790, 1988.

[18] M. F. Rivas-Crespo, L. Minones-Suarez, and S. S. G-Gallarza, "Rare neonatal diabetes insipidus and associated late risks: case report," BMC Pediatrics, vol. 12, article 56, 2012.

[19] E. J. Blanco, A. H. Lane, N. Aijaz, D. Blumberg, and T. A. Wilson, "Use of subcutaneous DDAVP in infants with central diabetes insipidus," Journal of Pediatric Endocrinology \& Metabolism: JPEM, vol. 19, no. 7, pp. 919-925, 2006.

[20] Y. Oiso, G. L. Robertson, J. P. Nørgaard, and K. V. Juul, "Treatment of neurohypophyseal diabetes insipidus," Journal of Clinical Endocrinology and Metabolism, vol. 98, no. 10, pp. 39583967, 2013.

[21] P. Thompson Jr., J. M. Earll, and M. Schaaf, "Comparison of clofibrate and chlorpropamide in vasopressin-responsive diabetes insipidus," Metabolism: Clinical and Experimental, vol. 26, no. 7, pp. 749-762, 1977.

[22] A. M. Moses, P. Numann, and M. Miller, "Mechanism of chlorpropamide-induced antidiuresis in man: evidence for release of $\mathrm{ADH}$ and enhancement of peripheral action," Metabolism, vol. 22, no. 1, pp. 59-66, 1973.

[23] A. M. Moses, J. Howanitz, M. van Gemert, and M. Miller, "Clofibrate-induced antidiuresis.," Journal of Clinical Investigation, vol. 52, no. 3, pp. 535-542, 1973.

[24] D. Andreani, G. A. Cinotti, and G. Stirati, "Chlorpropamide in idiopathic diabetes insipidus," Metabolism, vol. 18, no. 10, pp. 874-877, 1969.

[25] J. Loffing, "Paradoxical antidiuretic effect of thiazides in diabetes insipidus: another piece in the puzzle," Journal of the American Society of Nephrology, vol. 15, no. 11, pp. 2948-2950, 2004.

[26] A. J. Magaldi, "New insights into the paradoxical effect of thiazides in diabetes insipidus therapy," Nephrology, Dialysis, Transplantation, vol. 15, no. 12, pp. 1903-1905, 2000.

[27] S. J. Fomon, "Potential renal solute load: considerations relating to complementary feedings of breastfed infants," Pediatrics, vol. 106, no. 5, article 1284, 2000.

[28] E. E. Ziegler and S. J. Fomon, "Potential renal solute load of infant formulas," The Journal of Nutrition, vol. 119, 12, pp. 17851788, 1989. 


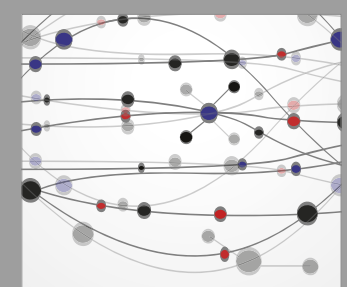

The Scientific World Journal
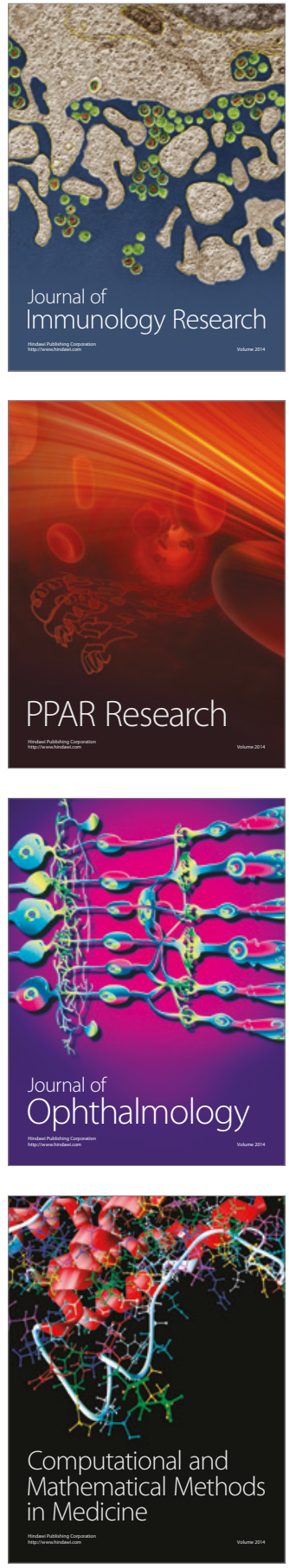

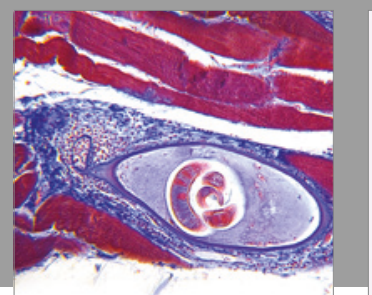

Gastroenterology Research and Practice
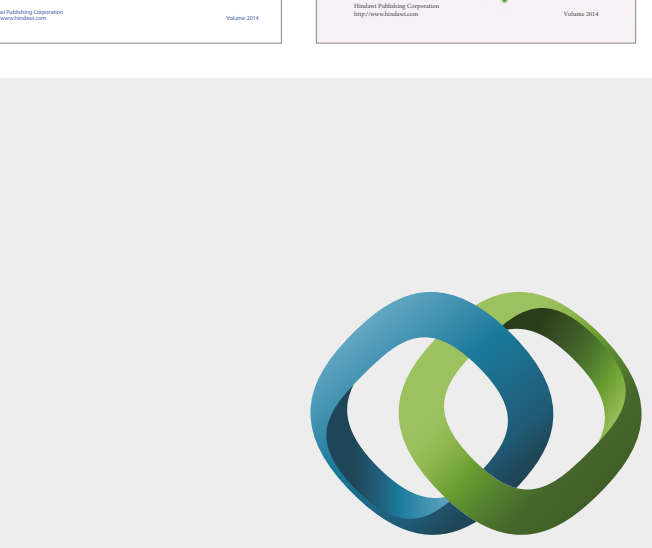

\section{Hindawi}

Submit your manuscripts at

https://www.hindawi.com
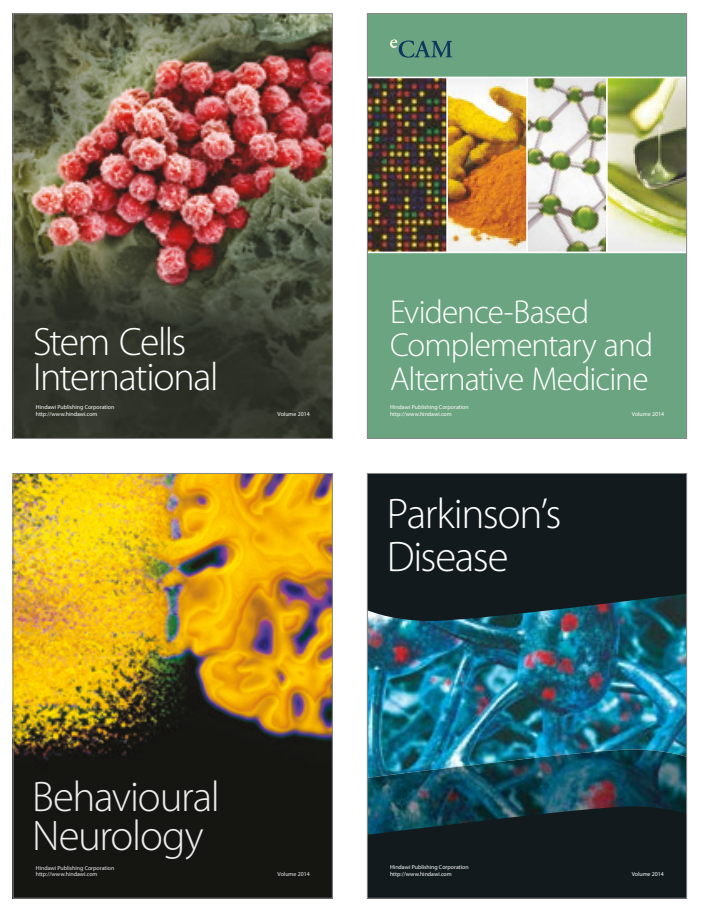
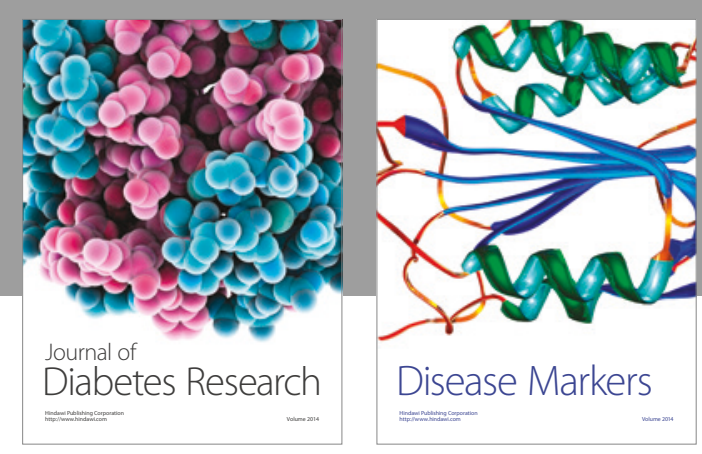

Disease Markers
